DOI: http://dx.doi.org/10.4314/giedr.v11i2.4

GLOBAL JOURNAL OF EDUCATIONAL RESEARCH VOL 11, NO. 2, 2012: 99-106

COPYRIGHT@ BACHUDO SCIENCE CO. LTD PRINTED IN NIGERIA. ISSN 1596-6224

99 www.globaljournalseries.com; Info@globaljournalseries.com

\title{
ASSESSMENT OF FACTORS DETERMINING PARENTS' PREFERENCE FOR PRIVATE SECONDARY SCHOOLS IN RURAL COMMUNITIES OF CROSS RIVER STATE
}

\author{
C. O. UKPOR; I. O. UBI AND A. E. OKON
}

(Received 12, June 2012; Revision Accepted 3, August 2012)

\begin{abstract}
This paper explored the underlying factors determining parents' choice of sending their children/wards to private secondary schools, using Cross River State rural communities as a case study. Sixty (60) private secondary institutions in the state were selected through stratified sampling technique. A total of 720 respondents were used in the study. This comprised 360 parents (males 153 and females 207) 300 teachers and 60 principals. The study used two sets of questionnaire: Parents' Patronage of Private School Questionnaire (PPPSQ) and Teachers' Opinion on Parents' Patronage of Private Schools Questionnaire (TOPPSQ). Survey design was adopted and percentages, and frequencies techniques were used. The study found out that private secondary schools in the area were highly patronized by parents who were influenced by pride of school ownership, effective monitoring of school activities by proprietors, high level of students achievement among other factors. One of the recommendations made was that government should adhere strictly to maintenance of high quality of school facilities and standard in order to avoid mediocre schools.
\end{abstract}

KEY WORDS: Assessment, Parents' Patronage, Rural, Private - Schools.

\section{INTRODUCTION}

Education in Cross River State of Nigeria and in some other parts of the world has been emancipated from the strictures of service to the few to freedom of educational opportunity for many. This is demonstrated in different ways across the globe, for instance the policy of No Child Left Behind (NCLB) was launched in January, 2002 in USA to take care of students from economically disadvantaged homes attending public schools, and in Nigeria there is a target programme Tagged Education For All (EFA) by the year 2020 aimed at educating all children (Smith, 2007). Also, with the realization that education in Nigeria is consumer oriented and that the country needs to move decisively from consumer to a manufacturing and selfreliant nation. Many educational avenues were created to couchin the effect of educational backwardness (Fafunwa, 1995).

One observable way education is made to reach every nook and cranny was the shift in the ownership, management and control of education industry which in some cases there is increase role of governments but in other cases there is a reduction in government role. In recent times, private ownership, management and control is being rejuvenated in Nigeria, a development that is supported by the Federal Government privatization policy of 1999. Earlier in 1985 the government promulgated Decree No 16 (now reviewed) specifying minimum standards

C. O. Ukpor, Department of Educational Foundations, Guidance and Counselling, Faculty of Education, University of Calabar, Calabar, Nigeria

I. O. Ubi, Department of Educational Foundations, Guidance and Counselling, Faculty of Education, University of Calabar, Calabar, Nigeria

A. E. Okon, Department of Educational Foundations, Guidance and Counselling, Faculty of Education, University of Calabar, Calabar, Nigeria 
for establishing primary and secondary schools nationwide.

Based on these guides on minimum standards and coupled with the policy of privatization, many individuals, religious organizations and communities in Cross River State of Nigeria decided to key into the business of owning and running schools. In view of the interest shown by many communities and individuals to become school proprietors irrespective of their financial standing, Eleckwachi (1999) opined that government should intensify supervision of private schools, and possibly aid voluntary agencies with funds to avoid craze for profit in the sub sector. Eleckwachi noted that most investors in the education industry were more interested in the net present value of the return on their investment.

Many researchers have expressed concern on the concept of quality and quantity of education. They observed that the indicators of quality could be categorized as material, physical and financial resources. Hence, these resources are components of instruments which people used in evaluating the effectiveness of schools (Fuller, 1996; Obemeata, 1999 and Mc Ewan, 2000).

In a comparative study of private (Catholic) and public secondary schools effectiveness in USA, Mc Ewan (2000) found that private secondary schools did not show statistically significant effects on achievement when compared with public schools but on attainment, evidence suggests that catholic/private schools have consistent effects on improving rates of high school graduation and college attendance, especially for minority students in urban areas. In Abeokuta Nigeria, Onuka and Arowojolu (2008) found that parents patronized private primary schools more than their public schools counterparts with reasons that private schools are of higher quality in spite of its high fees charged. The question now is, what instigates the proliferation of private secondary schools in Cross River State with particular reference to rural communities? This study sought to find out the factors determining parents' preference for private secondary schools in Cross River State (CRS) rural communities.

\section{Problem of the study}

Over the last two decades private secondary schools have proliferated in Cross
River State of Nigeria, an unprecedented development that has come at the wake of federal government privatization policy and the enabling policy of minimum standards of primary and secondary schools. The result of this proliferation in the education subsector is competition between private and public schools for patronage from parents (Customers). How do private secondary schools in rural communities cope with the competition for parents' patronage? What motivates parents to prefer sending their wards to private secondary schools?

\section{Research questions}

To guide this study the following specific questions were asked:

i. How does proprietorial interest influence parents' patronage of private secondary schools in Cross River State (CRS) rural communities?

ii. How does the quality of physical facilities influence parent's patronage of private secondary schools?

iii. What is the relationship between pattern of supervision and parents' patronage of private secondary schools?

\section{Methodology}

Seven hundred and twenty (720) respondents were sampled from the three (3) senatorial districts in Cross River State and used for the study. As at August, 2011, there were 335 accredited private secondary schools (both urban and rural) in the state who have written the Senior School Certificate Examinations (SSCE) (M.O.E, 2011).One hundred and seventy-four (174) of the 335 were classified as rural schools by the researchers.

Through stratified random sampling technique, 60 schools were selected. The 3 senatorial districts (Southern, central and northern) which coincided with the three (3) Educational Zones (Calabar, Ikom and Ogoja) respectively formed the basis for stratification. In each zone, 35 percent of the rural schools were randomly selected. Systematic sampling technique was applied in selecting 360 parents (153 males and 207 females). Parents whose children or wards' serial number fall on 5 in six selected class attendant registers, from Junior Secondary One (JS1) to Senior Secondary Three (SS3) were chosen. Also randomly picked from 
each school were five (5) teachers and the principal or the vice principal.

The researchers and their assistants directly administered the questionnaire on the respondents which lasted for twelve (12) weeks. There was 100 percent return of the questionnaire used. In most cases the instrument administered were collected on the spot.

\section{RESULTS}

The factors determining parents' preference for private schools are shown in Table 1 , while Table 2 is on Teachers' opinion about the choice of schools by parents.

TABLE 1: Factors determining parents' patronage of private secondary schools opinion in Cross River State rural areas (PPPSQ)

\begin{tabular}{|c|c|c|c|c|c|c|}
\hline ITEM & STATEMENT & No & SA & $\mathbf{A}$ & D & SD \\
\hline 1. & Students pay less fare to and from school & 100 & $\begin{array}{l}16 \\
(16 \%)\end{array}$ & $\begin{array}{l}37 \\
(37 \%)\end{array}$ & $\begin{array}{l}24 \\
(24 \%)\end{array}$ & $\begin{array}{l}23 \\
(23 \%)\end{array}$ \\
\hline 2. & $\begin{array}{l}\text { Students pay tuition fee once and sit for } \\
\text { WASSCE and NECO/SSCE in a session }\end{array}$ & 100 & $\begin{array}{l}36 \\
(36 \%) \\
\end{array}$ & $\begin{array}{l}31 \\
(31 \%)\end{array}$ & $\begin{array}{l}17 \\
(17 \%)\end{array}$ & $\begin{array}{l}16 \\
(16 \%)\end{array}$ \\
\hline 3. & $\begin{array}{l}\text { Admission from primary to secondary school is } \\
\text { easy }\end{array}$ & 100 & $\begin{array}{l}18 \\
(18 \%)\end{array}$ & $\begin{array}{l}39 \\
(39 \%)\end{array}$ & $\begin{array}{l}34 \\
(34 \%)\end{array}$ & $\begin{array}{l}9 \\
(9 \%)\end{array}$ \\
\hline 4. & No strike & 100 & $\begin{array}{l}36 \\
(36 \%)\end{array}$ & $\begin{array}{l}32 \\
(32 \%)\end{array}$ & $\begin{array}{l}16 \\
(16 \%)\end{array}$ & $\begin{array}{l}16 \\
(16 \%)\end{array}$ \\
\hline 5. & Ownership interest & 100 & $\begin{array}{l}40 \\
(40 \%)\end{array}$ & $\begin{array}{l}31 \\
(31 \%)\end{array}$ & $\begin{array}{l}20 \\
(20 \%)\end{array}$ & $\begin{array}{l}9 \\
(9 \%)\end{array}$ \\
\hline 6. & $\begin{array}{l}\text { Effective monitoring of school activities by } \\
\text { proprietors }\end{array}$ & 100 & $\begin{array}{l}16 \\
(16 \%)\end{array}$ & $\begin{array}{l}42 \\
(42 \%)\end{array}$ & $\begin{array}{l}30 \\
(30 \%)\end{array}$ & $\begin{array}{l}12 \\
(12 \%)\end{array}$ \\
\hline 7. & $\begin{array}{l}\text { Opportunity of leaving secondary school in } \\
\text { record time. }\end{array}$ & 100 & $\begin{array}{l}41 \\
(41 \%)\end{array}$ & $\begin{array}{l}18 \\
(18 \%)\end{array}$ & $\begin{array}{l}21 \\
(21 \%)\end{array}$ & $\begin{array}{l}20 \\
(20 \%)\end{array}$ \\
\hline 8. & Student makes good results. & 100 & $\begin{array}{l}21 \\
(21 \%)\end{array}$ & $\begin{array}{l}42 \\
(42 \%)\end{array}$ & $\begin{array}{l}29 \\
(29 \%)\end{array}$ & $\begin{array}{l}8 \\
(8 \%)\end{array}$ \\
\hline 9. & $\begin{array}{l}\text { Ease of students registration during WASSCE } \\
\text { and NECO SSCE. }\end{array}$ & 100 & $\begin{array}{l}20 \\
(20 \%)\end{array}$ & $\begin{array}{l}40 \\
(40 \%)\end{array}$ & $\begin{array}{l}25 \\
(25 \%)\end{array}$ & $\begin{array}{l}15 \\
(15 \%)\end{array}$ \\
\hline 10. & $\begin{array}{l}\text { Smooth transition from Junior to Senior } \\
\text { secondary levels. }\end{array}$ & 100 & $\begin{array}{l}21 \\
(21 \%)\end{array}$ & $\begin{array}{l}40 \\
(40 \%)\end{array}$ & $\begin{array}{l}28 \\
(28 \%)\end{array}$ & $\begin{array}{l}11 \\
(11 \%)\end{array}$ \\
\hline 11. & Prompt attention to students problem & 100 & $\begin{array}{l}14 \\
(14 \%)\end{array}$ & $\begin{array}{l}50 \\
50 \%\end{array}$ & $\begin{array}{l}20 \\
20 \%\end{array}$ & $\begin{array}{l}16 \\
16 \%\end{array}$ \\
\hline & Average & 100 & 25.36 & 36.54 & 21.82 & 16.28 \\
\hline
\end{tabular}

It would be observed from Table 1 that all the eleven (11) identified and enumerated factors as influencing parents choice actually acted as instigators of parents' patronage of private secondary schools in Cross River State rural areas. Analysis of the data revealed that $62 \%$ of parents in the sample agreed that they were influenced by the following factors: low cost of transportation; payment of tuition fee once and sitting for WASSCE and NECO-SSCE; ease of admission; no strike action; ownership interest; effective monitoring of schools and leaving school in record time. Others are making of good results; ease of registration; smooth transition from JS1 to SS3 and prompt attention to students problems. A close observation depicts that the 11 items fall into 5 categories which are prompt attention given to students' needs, effective teaching and learning, cost effectiveness, good results and pride of ownership.

Items 1,2 and 7 in section B of the PPPSQ show that parents preference for private secondary schools in Cross River State rural communities was encouraged by its cost effectiveness (proximity to the schools, avenue to pay tuition fee once and sit for West African Senior Secondary Certificate Examination (WASSCE) and National Examination Council Senior School Certificate Examination (NECO, SSCE) and opportunity for leaving school in 
record time. Items $3,9,10$ and 11 of the PPPSQ fall into the category of prompt attention given to students problems, that is, there is less administrative bottle-neck, and $60.5 \%$ of the parents agreed to these factors as influencing their choice of private schools.

The third category is pride of ownership in which items 5 and 6 constitute its components, that is, $64.5 \%$ of the parents are influenced by these factors to patronize private secondary schools. Item 4 measures effective time on task and $68 \%$ of parents agreed that they are influenced by this factor to send their children to private secondary schools. Item 8 measures opportunity for students to make good results at the senior secondary 3 (SS3) level and $63 \%$ of the sampled parents indicated that to make a good pass at the end of school year instigated them to patronize private secondary schools in the area.

TABLE 2: Teacher's opinion on parents' patronage of private secondary schools

\begin{tabular}{|l|l|l|l|l|}
\hline Item & Statement: in my school & No & Agree & Disagree \\
\hline 1. & Parent relationship with teachers is not cordial & 100 & $\begin{array}{l}29 \\
(29 \%)\end{array}$ & $\begin{array}{l}71 \\
(71 \%)\end{array}$ \\
\hline 2. & $\begin{array}{l}\text { Parents are highly interested in the education of } \\
\text { their children. }\end{array}$ & 100 & $\begin{array}{l}76 \\
(76 \%)\end{array}$ & $\begin{array}{l}24 \\
(24 \%)\end{array}$ \\
\hline 3. & Teachers have adequate teaching qualifications. & 100 & $\begin{array}{l}55 \\
(55 \%)\end{array}$ & $\begin{array}{l}45 \\
(45 \%)\end{array}$ \\
\hline 4. & Teachers work load is high. & 100 & $\begin{array}{l}51 \\
(51 \%)\end{array}$ & $\begin{array}{l}49 \\
(49 \%)\end{array}$ \\
\hline 5. & Teachers are not highly discipline. & 100 & $\begin{array}{l}24 \\
(24 \%)\end{array}$ & $\begin{array}{l}76 \\
(76 \%)\end{array}$ \\
\hline 6. & $\begin{array}{l}\text { Supervision of teachers by administration is } \\
\text { quite adequate. }\end{array}$ & 100 & $\begin{array}{l}75 \\
(75 \%)\end{array}$ & $\begin{array}{l}25 \\
(25 \%)\end{array}$ \\
\hline 7. & $\begin{array}{l}\text { Parents provide students with basic learning } \\
\text { materials. }\end{array}$ & 100 & $\begin{array}{l}66 \\
(66 \%)\end{array}$ & $\begin{array}{l}34 \\
(34 \%)\end{array}$ \\
\hline 8. & Teachers time on task is quite high. & 100 & $\begin{array}{l}67 \\
(67 \%)\end{array}$ & $\begin{array}{l}33 \\
(33 \%)\end{array}$ \\
\hline 9. & Students are very discipline. & 100 & $\begin{array}{l}69 \\
(69 \%)\end{array}$ & $\begin{array}{l}31 \\
(31 \%)\end{array}$ \\
\hline 10. & Extra curricular activities are not encouraged. & 100 & $\begin{array}{l}16 \\
(16 \%)\end{array}$ & $\begin{array}{l}84 \\
(84 \%)\end{array}$ \\
\hline 11. & $\begin{array}{l}\text { Parents freely discuss their children problems } \\
\text { with the teachers. }\end{array}$ & 100 & $\begin{array}{l}65 \\
(65 \%)\end{array}$ & $\begin{array}{l}35 \\
(35 \%)\end{array}$ \\
\hline
\end{tabular}

Table 2 which depicts teachers opinion on parents' patronage of private secondary schools in Cross River State rural area reveal the following: that there is cordial relationship between teachers and parents as measured by items $1,2,7$ and 11, with a mean response of $69.5 \%$ in agreement to the items, that there is high quality of education in private secondary school in Cross River State Rural Areas, this is as revealed in items 3, 5, 6 and 9. Item 3 has $55.2 \%$, that teachers quality is adequate. Item 5 with $76 \%$ depicts that teachers are highly discipline while item 6 which measures teachers' supervision by the administrators of schools has $75.2 \%$ that their activities are highly monitored and $69 \%$ agreed that the students are equally discipline as shown in item 9 of TOPPSQ.

Item 4 and 8 with responses of $51 \%$ and $67 \%$ respectively measure the commitment of teachers to duties which show that the teachers in private secondary schools are quite committed to their primary assignment of teaching. Extra curricular activities also endeared parents to private secondary schools as teachers opinion to the item, 10 , is $84 \%$ in support. 
TABLE 3: Summary of quality of physical facilities

\begin{tabular}{lllll}
\hline Variables & Yes & $\%$ & No & $\%$ \\
\hline Standard football field & 15 & 25 & 45 & 75 \\
3 standard science laboratories & 25 & 42 & 35 & 58 \\
Standard dinning hall & 3 & 5 & 57 & 95 \\
Adequate library & 10 & 17 & 50 & 83 \\
Adequate farm land & 42 & 70 & 18 & 30 \\
Adequate Toilet facilities & 45 & 75 & 15 & 25 \\
Constant electricity supply & 32 & 53 & 28 & 47 \\
Standard classroom & 41 & 68 & 19 & 32 \\
Functional computer centre & 4 & 7 & 56 & 93 \\
Well equipped sick bay & 10 & 17 & 50 & 83 \\
\hline \hline
\end{tabular}

The result in Table 3 shows that none of the sixty private secondary schools in Cross River State rural communities is well equipped by the proprietors. The data revealed that none of the schools have standard football fields, adequate library, dinning facilities, functional computer centre and well equipped sick-bay.

However, $68 \%$ to $75 \%$ of the schools have standard classrooms, agricultural land and
VIP toilet facilities. Laboratories have $42 \%$ which means $67 \%$ of the schools have met the required standard set by the ministry of education. On the average the rural schools have scored $40 \%$ based on the quality of physical facilities available. As at the time of this study all the schools have accreditation by the ministry of education.

TABLE 4: Why parents do not patronage public secondary schools in Cross River State Rural Area

\begin{tabular}{|c|c|c|c|c|c|c|}
\hline Item & Statement: & No & SD & A & $\mathrm{D}$ & SD \\
\hline 1. & Poor monitoring and supervision of students' work. & 100 & $\begin{array}{l}30 \\
(30 \%)\end{array}$ & $\begin{array}{l}33 \\
(33 \%)\end{array}$ & $\begin{array}{l}20 \\
(20 \%)\end{array}$ & $\begin{array}{l}17 \\
(17 \%)\end{array}$ \\
\hline 2. & High level of indiscipline among students. & 100 & $\begin{array}{l}15 \\
(15 \%)\end{array}$ & $\begin{array}{l}42 \\
(42 \%)\end{array}$ & $\begin{array}{l}35 \\
(35 \%)\end{array}$ & $\begin{array}{l}13 \\
(13 \%)\end{array}$ \\
\hline 3. & Frequent strike action. & 100 & $\begin{array}{l}32 \\
(32 \%)\end{array}$ & $\begin{array}{l}32 \\
(32 \%)\end{array}$ & $\begin{array}{l}26 \\
(26 \%)\end{array}$ & $\begin{array}{l}10 \\
(10 \%)\end{array}$ \\
\hline 4. & Congestion in classrooms. & 100 & $\begin{array}{l}15 \\
(15 \%)\end{array}$ & $\begin{array}{l}36 \\
(36 \%)\end{array}$ & $\begin{array}{l}25 \\
(25 \%)\end{array}$ & $\begin{array}{l}24 \\
(24 \%)\end{array}$ \\
\hline 5. & Poor public relation with parents. & 100 & $\begin{array}{l}20 \\
(20 \%)\end{array}$ & $\begin{array}{l}45 \\
(45 \%)\end{array}$ & $\begin{array}{l}20 \\
(20 \%)\end{array}$ & $\begin{array}{l}15 \\
(15 \%)\end{array}$ \\
\hline 6. & Teachers are not committed to their work. & 100 & $\begin{array}{l}18 \\
(18 \%)\end{array}$ & $\begin{array}{l}44 \\
(44 \%)\end{array}$ & $\begin{array}{l}24 \\
(24 \%)\end{array}$ & $\begin{array}{l}14 \\
(14 \%)\end{array}$ \\
\hline 7. & Action is delayed on issue requiring urgent attention. & 100 & $\begin{array}{l}18 \\
(18 \%)\end{array}$ & $\begin{array}{l}35 \\
(35 \%)\end{array}$ & $\begin{array}{l}30 \\
(30 \%)\end{array}$ & $\begin{array}{l}17 \\
(17 \%)\end{array}$ \\
\hline 8. & Low standard of education. & 100 & $\begin{array}{l}25 \\
(25 \%)\end{array}$ & $\begin{array}{l}37 \\
(37 \%)\end{array}$ & $\begin{array}{l}19 \\
(19 \%)\end{array}$ & $\begin{array}{l}19 \\
(19 \%)\end{array}$ \\
\hline 9. & Difficulty in gaining admission. & 100 & $\begin{array}{l}10 \\
(10 \%)\end{array}$ & $\begin{array}{l}45 \\
(45 \%)\end{array}$ & $\begin{array}{l}23 \\
(23 \%)\end{array}$ & $\begin{array}{l}22 \\
(22 \%)\end{array}$ \\
\hline 10. & Shortage of teachers. & 100 & $\begin{array}{l}11 \\
(11 \%)\end{array}$ & $\begin{array}{l}40 \\
(40 \%)\end{array}$ & $\begin{array}{l}35 \\
(35 \%) \\
\end{array}$ & $\begin{array}{l}10 \\
(10 \%)\end{array}$ \\
\hline
\end{tabular}


It could be observed from Table 4 that there are 10 items which are categorized into three (3):

1. Facilities (human and materials) as is depicted in items 4 and 10 in which $51 \%$ of both items received a response of poor facilities.

2. Low standard of education is measured by items 1,2,3,6 and 8 in which the average responses from parents is $61.6 \%$ stated that they did not patronize public schools because the standard of education is low.

3. Delay in attending to issues of urgent or immediate attention which is revealed in items 5,7 and 9 whose average gives $59.7 \%$ agreement that public schools are characterized by protocols that work against their efficiency.

\section{DISCUSSION}

A number of factors have been identified and listed on PPPSQ as stimulants for parents' patronage of private secondary schools in rural communities of Cross River State (CRS), Nigeria. These factors or items fall into five (5) categories namely: prompt attention paid to students and parents when the need arises, effective teaching and learning, cost effectiveness, good results at senior school certificate examination level and pride of being school proprietors.

In responses to research question one: How does proprietorial interest influence parents' patronage of private secondary schools in Cross River State rural areas. The finding of this study revealed that most of the parents are members of the communities where the schools are located and that the parents feel highly honoured to be addressed as proprietors and proprietresses. The pride of proprietorial status spurs them to patronize their own property or enterprise. Item 5 on the PPPSQ which measures pride of ownership records $71 \%$ agreements as reason for parents patronage of private secondary schools in Cross River State.

In addition, the finding on PPPSQ is in agreement with Onuka and Arowojulu (2008) and Onuka (2005) who found that private primary schools are patronized by parents because children in these schools are given close attention and that there is effective monitoring of children learning. However, the finding of this study that parents patronize private secondary schools for reason that students do register or record high achievement at SSCE contradicts Mc
Ewan (2000) whose study did not show significant effect on achievement of private (catholic) schools and public school in USA.

Research question two (2): How does the quality of physical facilities influence parents' patronage of private secondary schools in Cross River State rural communities? The finding of this study with respect to the second research, question could be deduced from Table 3, that the quality of physical facilities did not strongly influence parents patronage of private institutions in Cross River State rural communities. This finding contradicts the finding of Onuka and Arowojolu (2008) that availability of quality facilities spured parents' patronage of private primary schools in Abeokuta.

On the relationship between pattern of supervision and parents patronage of private schools as anchored in research question three (3), it was found out in this study that both parents and teachers indicated that there is effective monitoring of school activities by proprietors in private schools which makes parents to choose such schools for their children/wards. Parents indicated that students in public schools are poorly monitored. The finding also reveals that students in public secondary schools exhibit high level of indiscipline probably as a result of poor commitment of teachers to their duty. This conforms with the finding of Onuka and Arowojolu (2008) that the weekly supervision of teachers' diaries, registers and lessons notes has significant effect on students achievement, which eventually encourages parents patronage of private primary schools.

The finding of this study on proprietorial supervision of teachers' and students' activities conforms with the finding of Adason and $\mathrm{Li}$ (1999) that private ownership of schools in the Asian and pacific regions was gaining momentum as a result of more commitment on the part of the proprietors of private schools and the associated achievement recorded. The finding added that the pendulum of school ownership has swung back to private schools.

This study also discovered that private secondary institutions in Cross River State have moderate number of students per class, which according to the FME (2004) stipulates the number of students per class to be an average of 40 , this encourages parents to patronize private schools as against their public school counterparts. This finding is in conformity with the finding of Adesina (1984) that large school 
population and congested classrooms in public schools with no corresponding increase in number of teachers was responsible for parents' increased interest in private schools.

\section{CONCLUSION}

It is revealed in the study that most parents choose to patronize private secondary schools in Cross River State rural communities because they have a stake in the schools as proprietors and proprietress and would therefore ensure that their schools succeed. The findings also showed that the quality of school facilities does not strongly influence parents' choice of private schools. However, effective supervision of school activities, making of good results, higher standard of education and high level of discipline as against public schools in the area encourage parents' patronage of private institutions.

\section{RECOMMENDATIONS}

The following recommendations were made based on the findings of this study:

All community members and other parents should be made to have more sense of belonging as proprietors and stakeholders of their schools to enable them show more interest in supporting the school, and sustaining such support.

The area of inadequate facilities should be intensively addressed in order to further raise the quality of students and the corresponding rise in education standard. Specifically, the laboratories, libraries and computer facilities should be upgraded and made functional.

Government should ensure that favourable school environment like adequate teaching facilities, sufficient number of teachers, standard school buildings with spacious classrooms, well equipped laboratories and libraries, are provided in public secondary schools. It is believed this will enhance high standard of quality education in the area.

The inspectorate division of the ministry of education should be made more functional in order to ensure strict adherence to the provisions of the national policy on education with particular reference to quality and standards in school. If this is well adhered to it is believed will eliminate mediocre private secondary schools whose proprietors' interest would mainly be on self enrichment.

\section{REFERENCES}

Adesina, S., 2004. Growth without development, an Inaugural delivered at the University of llorin, llorin.

Eleckwachi, I. A., 1999. Issues in the cost benefit analysis of Private sector investment in education. J. O. Obemeata (ed). Evaluation in Africa. P.139 -144.

Fafunwa, A. B., 1995. History of Education in Nigeria. NPS Educational Publishers Ibadan.

Federal Republic of Nigeria (FRN). 2004. National Policy on Education ( $4^{\text {th }} \mathrm{ed}$ ) Abuja, NERDC.

Fuller, B., 1996. What school factors raise achievement in the third world. In review of Education Research 5 (3), 65 - 94.

Mc Ewan, P. J., 2000. Comparing the effectiveness of public and private schools a review of evidence and interpretations. Occasional paper No. 3 National centre for the study of privatization in Education. Teacher College, Columbia University. Retrieved wwwtcColumbia odu/ncspe on 20/8/2011.

Ministry of Education., 2011. School records: Classified document.

Ministry of Education Publication (MOE)., 2008. Regulations on Minimum Standard for the Establishment of Schools in Cross River State.

Obemeata, J. O., 1999. Education: An unprofitable industry in Nigeria. Postgraduate school interdisciplinary Research Discourse, University of Ilorin, llorin.

Onuka, A. O. U., 2005. A comparative study of quality of managers, teachers, and facilities of private and public primary schools in Ibadan, Oyo State, Nigeria. Journal of Educational Administration and Planning 5 (2) $210-216$. 
Onuka, A. O. U and Arowojolu, A. F., July, 2008. An evaluation of parents patronage of private primary schools in Abeokuta, Nigeria. International Journal of Africans, African - American Studies 7 (2) 58 - 70.
Retrieved from adamonuka @ yahoo.com on $28 / 8 / 201$.

Smith, E., 2007. Analyzing under achievement in schools. Empirical studies in education. Continuum international publishing gro up, London and New York. 